\title{
Flow Injection Determination of Calcium and Magnesium in Soluble Pharmaceutical Tablets by Flame Atomic Absorption Spectrometry Using Ultrasound for Sample Preparation
}

\author{
M.C. Yebra \\ Department of Analytical Chemistry, Nutrition and Bromatology \\ Faculty of Chemistry. University of Santiago de Compostela \\ Avda. das Ciencias, s/n \\ 15782 Santiago de Compostela, Spain
}

\section{INTRODUCTION}

Calcium and magnesium are essential elements in the human diet and the most abundant mineral in the human body. Calcium intervenes in numerous critical health functions such growth and reproduction, and is essential for the formation and maintenance of healthy bones and teeth. Magnesium is an essential mineral for the cellular operation and plays a key role in the reactions of the phosphates (1). Sometimes, ingestion of these minerals in the diet is not enough and vitamin supplements such as multivitamin tablets must be included in the normal diet. Therefore, there is great interest in the development of rapid and efficient methods for the analytical control of pharmaceutical products.

Usually, calcium and magnesium are determined by flame atomic absorption spectrometry (FAAS) since the sensitivity of the graphite furnace technique is rarely required (2). However, the problems involved in the determination of these elements by FAAS are the chemical interferences in the atomization cell when aluminum, silicon, and/or phosphates are present (34). These interferences decrease the absorbance signal and are usually eliminated by adding releasing agents. Releasing agents react pref-

*Corresponding autbor.

E-mail: mcarmen.yebra@usc.es.

Fax: 34981595012

\section{ABSTRACT}

A simple and rapid continuous manifold for sample dissolution based on ultrasound energy is evaluated for flow injection determination of calcium and magnesium in pharmaceutical tablets by flame atomic absorption spectrometry. Several parameters that could influence the dissolution process were evaluated by Plackett-Burman experimental designs. The obtained results showed that samples were easily dissolved with ultrapure water at room temperature at a flow-rate of $6 \mathrm{~mL} \mathrm{~min}{ }^{-1}$ under the action of ultrasound energy during 30 seconds. The analytical method was characterized and the limit of detection and limit of quantification for the two metals were 2.8 and $9.5 \mathrm{mg} \mathrm{g}^{-1}$ for $\mathrm{Ca}$ and 7.5 and $25 \mu \mathrm{g} \mathrm{g}^{-1}$ for $\mathrm{Mg}$, respectively. The sampling frequency of the system was about 50 samples per hour, with repeatability, expressed as relative standard deviation, in the range 0.5 and $3.0 \%$ for both metals. The proposed methodology was successfully applied to determine calcium and magnesium in multivitamin tablets.

erentially with the interfering species and avoid their reactions with the goal element. Thus, strontium (5) or lanthanum (6) are added as releasing agents in the determination of calcium and magnesium in several matrices. Further- more, before analysis (for most of the analytical detectors, including FAAS), a suitable dissolution of the solid sample is required. Thus, the total dissolution of the sample is the more common pretreatment, since this procedure avoids sample heterogeneity (7). For this purpose, solid samples usually require an extensive treatment with mineral acids under heating (8-11). If the sample is soluble, as with certain pharmaceutical preparations in the form of multivitamin tablets, the dissolution is usually carried out by manual or mechanical stirring with warming or at room temperature (12-13). In this context, ultrasound energy is of great help in the sample pretreatment. This energy facilitates and accelerates some analytical steps such as sample preparation, among others (14-15). Nevertheless, these off-line procedures are laborious and time-consuming because they involve large sonication times as well as a centrifugation step to separate the liquid phase. Continuous ultrasoundassisted procedures coupled to an on-line flow injection-flame atomic absorption spectrometric manifold (FI-FAAS) have been proposed to avoid these drawbacks (16-19), but this method has not yet been proposed for use in dissolving soluble solid pharmaceutical preparations.

In the present work, this last approach was adopted successfully for the determination of calcium and magnesium in soluble solid pharmaceutical preparations (multivitamin tablets). The samples were 


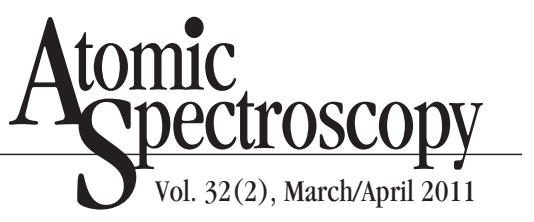

automatically dissolved and diluted on-line with a lanthanum salt (III) solution in order to mask chemical interferences for the continuous monitoring of calcium and magnesium by FAAS.

\section{EXPERIMENTAL}

\section{Instrumentation}

The manifold used (Figure 1) is composed of two Gilson ${ }^{\circledR}$ Minipuls ${ }^{\mathrm{TM}}-3$ peristaltic pumps (Gilson, Villiers Le Bel, France), fitted with PVC tubes, an ultrasonic bath with an ultrasound power of $40 \mathrm{KHz}$ (Selecta, Barcelona, Spain), and a glass minicolumn (50 $\mathrm{mm} \mathrm{x}$ $3 \mathrm{~mm}$ i.d., bed volume of $350 \mu \mathrm{L}$ ) (Omnifit, Cambridge, UK) used as sample container. The ends of the minicolumn were plugged with filter paper (Whatman 541) to retain the sample within the dissolution cell including any possible insoluble residue, four Rheodyne ${ }^{\circledR}$ injec- tion or switching valves, Models 5041 and 5301 (Rheodyne, Inc., Rohnert Park, CA, USA).

A PerkinElmer ${ }^{\circledR}$ Model 5000 atomic absorption spectrometer (PerkinElmer, Inc., Shelton, CT, USA) with a deuterium background corrector was used for calcium and magnesium measurements. Hollow cathode lamps (PerkinElmer, Inc.), operating at the recommended current, were used. This analytical instrument was furnished with the suitable hollow cathode lamp and was set at $422.7 \mathrm{~nm}$ or $285.2 \mathrm{~nm}$ for calcium and magnesium determination, respectively. A standard oxidizing air/acetylene flame was used. The spectrometer output was connected to a PerkinElmer Model 50 Servograph Recorder with a range of $5 \mathrm{mV}$. The signals measured were the height of the absorbance peaks, which can be obtained with an integration time of 3 seconds. Numerical analyses of experimental

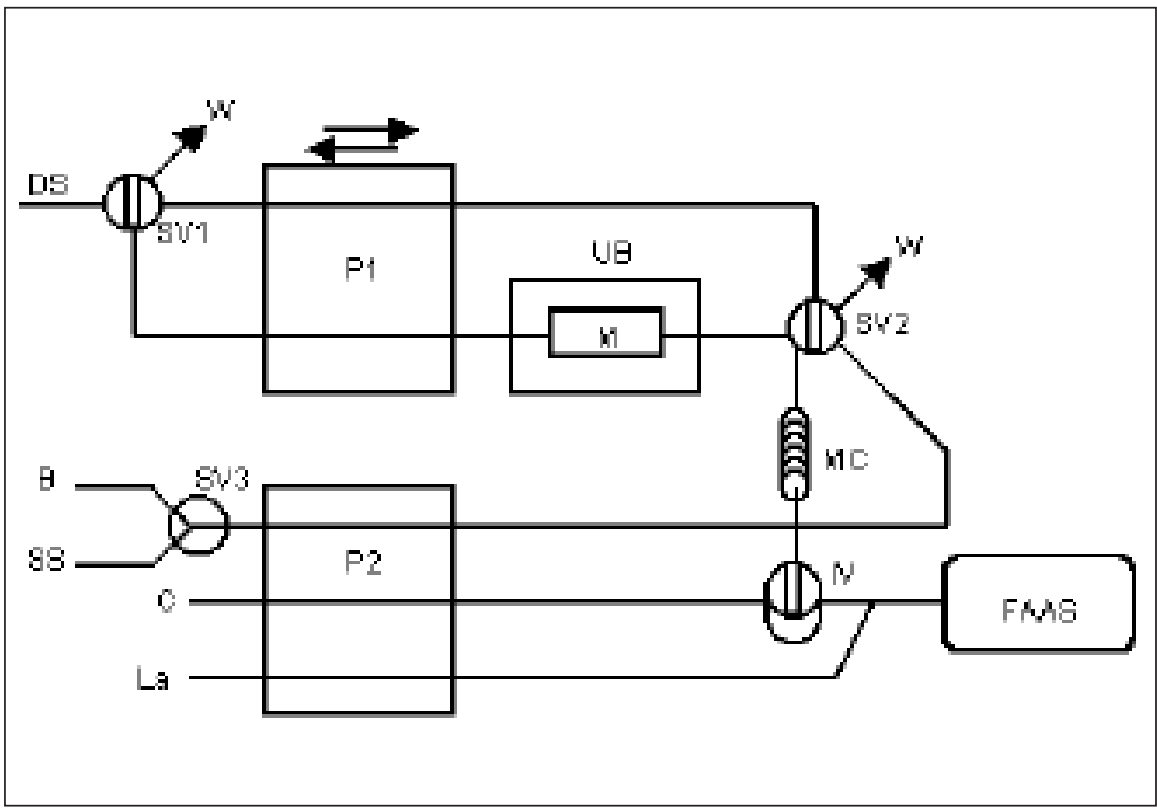

Fig. 1. Experimental set-up used for the continuous ultrasound assisted dissolution and FI determination of calcium and magnesium in soluble solid pharmaceutical samples. $P 1$ and P2, peristaltic pumps; DS, dissolving solution; W, waste; UB, ultrasonic bath; M, minicolumn containing the sample (dissolution cell); SS, standard solution; B, blank; IV, injection valve; SV1-SV3, switching valves; MC, mixing coil; $C$, carrier (ultrapure water); La, lanthanum solution and FAAS, flame atomic absorption spectrometer. designs were performed by means of the statistical package Statgraphics Plus 5.1 (Manugistic, Inc., Rockville, MD, USA).

\section{Reagents}

Chemicals were of ultrapure grade. Ultrapure water with a resistivity of $18.2 \mathrm{M} \Omega \mathrm{cm}^{-1}$ was obtained with a Milli-Q ${ }^{\mathrm{TM}}$ purification device (Millipore Corporation, Bedford, MA, USA). Calcium and magnesium stock standard solutions $\left(1000 \mu \mathrm{g} \mathrm{mL}^{-1}\right)$ were supplied by Merck (Darmstadt, Germany). Nitric acid 65\% and hydrochloric acid 30\% were obtained from Merck. The lanthanum solution $\left(0.15 \mathrm{~mol} \mathrm{~L}^{-1}\right)$ was prepared by dissolving $13.9278 \mathrm{~g}$ of $\mathrm{LaCl}_{3} \cdot 7 \mathrm{H}_{2} \mathrm{O}$ (Merck) in $250 \mathrm{~mL}$ of ultrapure water. All glassware was cleaned in $4 \mathrm{~mol} \mathrm{~L}^{-1}$ nitric acid for four days and rinsed with ultrapure water before use.

\section{Sample Preparation}

tHE Multivitamin tablets were purchased in local markets and pharmacies. THE Samples were manually ground and pulverized with a mortar into a fine powder, blended and homogenized, and finally sieved through a $0.1-\mathrm{mm}$ pore diameter plastic sieve. The samples were kept in clean dry containers.

\section{Procedure}

The samples (about $1 \mathrm{mg}$ ) were directly weighed into a glass minicolumn (dissolution cell). Each minicolumn was attached to the ultrasound-assisted dissolution system (Figure 1) and immersed into the ultrasonic bath (at room temperature, $20^{\circ} \mathrm{C}$ ). The continuous dissolution circuit was filled with the dissolving solution $(5 \mathrm{~mL}$ of ultrapure water). Once filled, the SV1 valve was switched to its other position and the dissolving solution circulated at $6.0 \mathrm{~mL} \mathrm{~min}^{-1}$ through the minicolumn for 0.5 minutes under ultrasonic treatment for sample dissolution. Then, the SV2 valve 
was switched to its other position and the dissolved sample homogenized into the mixing coil. Finally, the loop of the injection valve (IV) was filled with a total volume of $100 \mu \mathrm{L}$ of the sample solution. In order to obtain an analytical signal within the linear range of these metals and to avoid chemical interferences in the calcium and magnesium determinations, the sample solution was injected into an ultrapure water carrier stream that circulated at a flow rate of $0.3 \mathrm{~mL} \mathrm{~min}^{-1}$. This stream converges with a $0.15 \mathrm{~mol} \mathrm{~L}^{-1}$ lanthanum dilution channel circulating at a flow rate of $5.0 \mathrm{~mL} \mathrm{~min}^{-1}$. Once these two streams have converged, the diluted sample is transported to the FAAS detector. Standard solutions containing up to 85 and $8.5 \mu \mathrm{g} \mathrm{mL}^{-1}$ for calcium and magnesium, respectively, were introduced into the flow system as is shown in Figure 1.

\section{RESULTS AND DISCUSSION}

\section{Optimization of the Continuous Ultrasound-assisted Dissolution Step}

The variables studied were as follows: the nature and concentration of dissolving solution, sonication time, dissolution temperature, flow rate of the continuous dissolving system, dissolving solution volume, and the concentration of the lanthanum solution used as releasing agent and dilution solution. In order to study the behavior of these variables, a factorial Plackett-Bur$\operatorname{man} 2^{\wedge} 7^{*} 3 / 32$ plus one center point was built. This experimental design involves 13 non-randomized runs. In order to test the statistical significance of the effects, an ANOVA was employed by Statgraphics Plus 5.1. The variable response was \% dissolution efficiency $=(\mathrm{A} / \mathrm{B}) \times 100$, where $A$ is the concentration of the metal obtained with the continuous ultrasound-assisted procedure and $B$ is the metal concentration obtained by manual dissolution with a conventional digestion procedure with concentrated nitric acid and off-line FAAS detection. The lower and upper values given to each variable were chosen from the available data and experience gathered in previous experiments (Table I). The principal conclusion of this screening study is that only the concentration of the lanthanum solution is a statistically influential factor at the $95 \%$ confidence level in the range studied. This factor is affected by a positive sign which means that an increase of its value improves the \% dissolution efficiency. With regard to nonstatistically influential factors, all present positive estimated effects but their absolute values for these variables are very low. In this study it was verified that complete sample dissolution ( $1 \mathrm{mg}$ ) can be obtained with a dissolving solution consisting of $5 \mathrm{~mL}$ ultrapure water circulating through the dissolution cell at a flow rate of $6 \mathrm{~mL} \mathrm{~min}^{-1}$ and under ultrasonic irradiation for 0.5 minutes at $20{ }^{\circ} \mathrm{C}$. With these conditions, the analytical signal is within the linear range of these metals and the sampling frequency is favored. Based on these results, a new experimental design shifting in the direction of higher values of concentration for the lanthanum solution would be desirable. How- ever, due to its high cost, few experiments were carried out in order to obtain the minimum lanthanum concentration necessary to avoid chemical interferences. Thus, this variable was evaluated by using a univariate method for lanthanum solutions between 0.05-0.40 mol L $\mathrm{L}^{-1}$. The results showed that a $0.15 \mathrm{~mol} \mathrm{~L}^{-1}$ lanthanum solution was enough to avoid chemical interferences for calcium and magnesium determination.

Table I shows the optimum factor values chosen for the continuous ultrasound-assisted dissolution system. The particle size was also studied because this is another variable that can affect the dissolution process. By using the optimum conditions of the continuous system, particle sizes smaller than $0.03 \mathrm{~mm}$ and between $0.03-0.1 \mathrm{~mm}$ were tested. The results obtained indicated that this variable does not affect the extraction process within the range studied. This can be explained through the high energy supplied by the ultrasound energy (frequency of $40 \mathrm{KHz}$ ), which increases the contact between the solid sample and the dissolving solution. Other flow parameters involving calcium and magnesium determination were also optimized: length of the mixing coil, the injected volume of dissolved sam-

TABLE I

Factor Levels in Plackett Burman Factorial Designs With Their Optimum Values and Analytical Features of the Method for the Determination of $\mathrm{Ca}$ and $\mathrm{Mg}$ in Soluble Pharmaceutical Samples by FAAS

\begin{tabular}{|c|c|c|c|}
\hline Instrumental Parameters & Low & High & Optimum \\
\hline $\mathrm{HNO}_{3}$ concentration $\left(\mathrm{mol} \mathrm{L}^{-1}\right)$ & 0 & 3 & 0 \\
\hline $\mathrm{HCl}$ concentration $\left(\mathrm{mol} \mathrm{L}^{-1}\right)$ & 0 & 3 & 0 \\
\hline Sonication time (min) & 0.5 & 5 & 0.5 \\
\hline Dissolution temperature $\left({ }^{\circ} \mathrm{C}\right)$ & 20 & 70 & 20 \\
\hline $\begin{array}{l}\text { Flow rate of the continuous dissolving } \\
\text { system }\left(\mathrm{mL} \mathrm{min}^{-1}\right)\end{array}$ & 3.5 & 6 & 6 \\
\hline Dissolving solution volume $(\mathrm{mL})$ & 1 & 5 & 5 \\
\hline La solution concentration $\left(\mathrm{mol} \mathrm{L}^{-1}\right)$ & 0.05 & 0.40 & 0.15 \\
\hline
\end{tabular}


ple, the flow rate of the carrier solution (ultrapure water), and the flow rate of the dilution/releasing solution channel (La solution $\left.0.15 \mathrm{~mol} \mathrm{~L}^{-1}\right)$. The mixing coil length necessary to homogenize the dissolved sample was $300 \mathrm{~cm}$. The carrier and the dilution/releasing solution flow rates were established taking into account the necessary dilution for the determination of each metal in the dissolved sample in order to obtain an absorbance signal within the linear range of these metals. So, as a compromise, the values chosen for the flow rate of the carrier solution and the flow rate of the dilution/ releasing solution, were 0.3 and

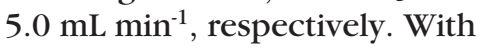
regard to the injected sample volume, $100 \mu \mathrm{L}$ was chosen because it allows at least three injections of each dissolved sample solution and verifies its homogeneity.

\section{Analytical Characteristics}

Operating the system at established conditions, linear calibrations were obtained for $\mathrm{Ca}$ and $\mathrm{Mg}$. For $\mathrm{Ca}$, the calibration was linear up to $85 \mu \mathrm{g} \mathrm{mL}^{-1}$ and the calibration equation obtained was $\mathrm{A}=1.8 \times 10^{-4}+$ $2.1 \times 10^{-3} \mathrm{C}$ (regression coefficient, $\mathrm{r}=0.999$ ). For $\mathrm{Mg}$, the calibration was linear up to $8.5 \mu \mathrm{g} \mathrm{mL}-1$ and the calibration equation obtained was
$\mathrm{A}=1.4 \times 10^{-4}+0.032 \mathrm{C}$ (regression coefficient, $r=0.999$ ), where $C$ is the concentration expressed in $\mu \mathrm{g} \mathrm{mL} \mathrm{L}^{-1}$ and $\mathrm{A}$ is the absorbance.

To evaluate the calcium and magnesium determination for possible sample matrix interferences, the standard addition method was performed. For this, a soluble multivitamin sample was spiked with several concentrations of these metals added to the dissolving solution. In these conditions, the addition calibration graphs were run $(n=7)$ under the optimal chemical and flow conditions for the global process. These equations and the corresponding calibration graphs present the same slope, demonstrating that the determination of these metals was free of matrix interferences. Therefore, one can make the calibration graphs with the $\mathrm{Ca}$ and Mg standard solutions to avoid the spiking process and thus speed up the analysis time.

For $1 \mathrm{mg}$ of sample, the limits of detection (LOD) and quantification (LOQ) for the two metals, calculated as the mass of analyte which gives a signal that is three times and 10 times, respectively, the standard deviation $(n=30)$ of the blank (ultrapure water), were 2.8 and $9.5 \mathrm{mg} \mathrm{g}^{-1}$ for $\mathrm{Ca}$ and 7.5 and $25 \mu \mathrm{g} \mathrm{g}^{-1}$ for $\mathrm{Mg}$, respectively. In

TABLE II

Determination of $\mathrm{Ca}$ and $\mathrm{Mg}$ in Soluble Pharmaceutical Samples and Paired $t$-test

\begin{tabular}{|c|c|c|c|c|}
\hline \multirow[t]{3}{*}{$\begin{array}{l}\text { Pharmaceutical } \\
\text { Samples }\end{array}$} & \multicolumn{4}{|c|}{$\begin{array}{c}\text { Concentration, mean } \pm \text { standard deviation }(n=3) \\
\text { (mg per tablet) }\end{array}$} \\
\hline & \multicolumn{2}{|c|}{$\mathrm{Ca}$} & \multicolumn{2}{|c|}{$\mathrm{Mg}$} \\
\hline & $\begin{array}{l}\text { Manual } \\
\text { Method }\end{array}$ & $\begin{array}{l}\text { Present } \\
\text { Method }\end{array}$ & $\begin{array}{l}\text { Manual } \\
\text { Method }\end{array}$ & $\begin{array}{l}\text { Present } \\
\text { Method }\end{array}$ \\
\hline $\begin{array}{l}\text { Multivitamin } \\
\text { Tablet } 1\end{array}$ & $174.8 \pm 6.1$ & $175.3 \pm 3.7$ & $50.5 \pm 0.8$ & $50.6 \pm 0.2$ \\
\hline $\begin{array}{l}\text { Multivitamin } \\
\text { Tablet } 2\end{array}$ & $50.1 \pm 1.7$ & $47.6 \pm 1.3$ & $39.5 \pm 0.7$ & $40.5 \pm 0.2$ \\
\hline $\begin{array}{l}\text { Multivitamin } \\
\text { Tablet } 3\end{array}$ & $161.1 \pm 4.9$ & $158.4 \pm 1.7$ & $30.3 \pm 0.7$ & $29.9 \pm 0.3$ \\
\hline
\end{tabular}

Critical value of $t(\mathrm{P}=0.05)=2.57$; experimental value of $t: 1.04$

\section{Atomic Apectroscopy \\ $\bigcirc$ Vol. 32(2), March/April 2011}

order to evaluate the precision of the proposed method, within-laboratory repeatability and reproducibility were estimated in a single experimental setup with duplicates for each metal. The experiments were carried out using the optimal conditions involving 11 replicates of a real sample on five days and 11 replicates on the same day. The repeatability, expressed as the relative standard deviation, ranged between 0.5 and $3.0 \%$; while the within-laboratory reproducibility ranged between 1.1 and $4.7 \%$ for both metals. The sample throughput of the method, taking into account the global process, was about 50 samples per hour.

\section{Application}

The proposed method was applied to soluble pharmaceutical samples (multivitamin tablets). The results of these analyses and their standard deviations $(n=3)$ are shown in Table II. In addition, the proposed methodology was compared with the results obtained by using the paired $t$-test with those obtained by manual sample dissolution by using a conventional procedure with concentrated nitric acid and off-line FAAS detection. As shown in Table II, the calculated $t$-value is smaller than that obtained from the $t$-distribution table (95\% confidence level). Thus, both groups of data do not give significantly different values and the agreement between them is satisfactory at the $95 \%$ confidence level.

\section{CONCLUSION}

In this study, $\mathrm{Ca}$ and $\mathrm{Mg}$ were determined by flame atomic absorption spectrometry (FAAS) using the continuous ultrasound-assisted dissolution system to dissolve automatically soluble multivitamin tablets by using ultrapure water at room temperature. A high sample throughput (50 samples $\mathrm{h}^{-1}$ ) was obtained, taking into account the whole analytical procedure, includ- 
ing the continuous dissolution, online sample dilution, and flow injection detection of the target analytes. The limits of detection and quantification for the two metals (2.8 and $9.5 \mathrm{mg} \mathrm{g}^{-1}$ for $\mathrm{Ca}$ and 7.5 and $25 \mu \mathrm{g} \mathrm{g}^{-1}$ for $\mathrm{Mg}$, respectively) are sufficient for application of the proposed method for the analysis of multivitamin samples. Furthermore, the automatic manifold provides better precision than manual methodologies because there are no losses due to intensive sample manipulation and it does not cause random errors associated with glassware calibration.

\section{ACKNOWLEDGMENT}

This work has been funded by Spain's Ministry of Science and Innovation within the framework of Project CTQ2009-12282.

Received September 1, 2010.

\section{REFERENCES}

1. J. Vormann, Mol. Aspect. Med. 24, 27 (2003).

2. R. Alonso-Bugallo, S. Río-Segade, and E. Fernández-Gómez, Talanta 72, 60 (2007)

3. A. R. Weisstaub, S. Zeni, M. L. de Portela, and P.A. Ronayne de Ferrera, J. Trace Elem. Med. Biol. 20, 41 (2006).

4. C. Sola-Larrañaga, and I. NavarroBlasco, Food Chem. 115, 3 (2009).

5. T.R. Crompton, Toxicants in Aqueous Ecosistems : a guide for the analytical and environmental chemist, Springer. Berlin (2007).

6. M. Pistón, I. Dol, and M. Knochen, J. Autom. Methods Manag. Chem. 1,6 (2006).

7. D. Kara, A. Fisher, and S. J. Hill, J. Hazard. Mat. 165, 1165 (2009).

8. R.W. Dabeka, and A.D. McKenzie, J. AOAC Int. 75, 954 (1992).

9. M.A. de la Fuente, G. Guerrero, and M. Juárez, J. Agric. Food Chem. 43, 2406 (1995).

10. A.N. Araújo, J. Gracia, J.L.F.C. Lima, M. Poch, M. Lúcia, and M.F.S. Saraiva, Fresenius J. Anal. Chem. 357, 1153 (1997).
11. J.L.F.C. Lima, C. Delerue-Matos, and M.C.V.F. Vaz, Food Chem 62, 117 (1998).

12. K. Chen, and S. Jiang, Anal. Chim. Acta, 470, 223 (2002).

13. S. Stürup, and A. Büchert, Fresenius J. Anal. Chem. 354, 323 (1996).

14. R.M. Cespón-Romero, and M.C. Yebra-Biurrun, Anal Chim Acta, 609,184 (2008).

15. M.C. Yebra, and R.M. Cespón, At. Spectrosc., 30, 41 (2009).

16. J.L. Capelo-Martínez (Ed.) Ultrasound in chemistry: analytical applications, Wiley-VCH. Weinheim (2009).

17. M.C. Yebra, A. Moreno-Cid, and S. Cancela, Talanta 62, 403 (2004).

18. F. Priego-Capote, and M.D. Luque de Castro, Anal. Bioanal. Chem. 378,1376 (2004).

19. M.C. Yebra, A. Moreno-Cid, and S. Cancela, Talanta 66, 691 (2005).

20. M.C. Yebra, S. Cancela, and A. Moreno-Cid, Anal. Chim. Acta 533, 51 (2005). 